PRODUCTION

ENGINEERING ARCHIVES
2015, Vol. 6, No 1, pp 6-9

ISSN 2353-5156 (print version)

ISSN 2353-7779 (online version)

\title{
Management of the basic characteristic of a supervisor and managerial position
}

\author{
Stanisław Borkowski \\ ${ }^{1}$ Czestochowa University of Technology, Faculty of Management, Institute of Production Engineering, e-mail: bork@zim.pcz.czest.pl
}

\begin{abstract}
The main focus in this chapter is diversification of the definitions of the following notions: leadership, supervision, management. The existence of various types of leaders, supervisors, managers has been emphasized. The supervisors' features were assessed based on the rules $4 \mathrm{E}+1 \mathrm{P}$, which prove their value in revealing the leadership characteristics of the management personnel.
\end{abstract}

Key words: leader, supervisor, manager, rules 4E+1P, BOST study

\section{Introduction}

Management is about securing (conscious creation) of conditions, so that a given organization runs according to its assumptions, i.e. executes its mission, reaches its relevant targets and maintains the necessary coherence which enables its survival, connected with the distinction in its environment and also the development, related to executing its mission and goals in the future. Therefore, the first step is to set the right course for an organization so that in the second stage it can follow the assigned direction as a well-guided ship (KoŹMIŃSKI A.K., JEMIELNIAK D. 2008). Management is an art of getting effects by way of subordinate people and other resources (NICKELS W.G. 1995). Leadership is the ability to "lead" smaller or bigger groups of followers. That ability refers to the skills of indicating and communicating the vision of future status or condition which needs to be jointly pursued. Leader- ship is all about enabling others to efficiently and enthusiastically work for achieving the assumed goals of an organization. A manager is a person managing a company or a selected area of its operations. The work of managers refers mostly to the company resources and to management. A manager is a person whose profession is managing an organization or its part with the use of specialist knowledge, methods and techniques of management. The person is considered responsible for directing the actions that lead to achieve the organization's goals. To a lesser extent, a manager is involved in directly managing a group of people, whereas to a large extent - in the most effective usage of organization resources, its development and functioning as a whole (FOŁTYN H. 2009).

In the theory of management, the basic characteristic of a supervisor is the managerial position in an organization hierarchy which is connected with such features as rank, remuneration, power and responsibil- 
ity. In specific conditions, the supervisor is called: foreman, supervisor, chief, co-ordinator, boss, head. There are also other terms substituting the name of 'a supervisor': leader, organizer, trainer, coach, ringleader, initiator, creator, animator, master (PocZTOWSKI A. 1998).

In the work of Nickels (NICKELS W.G. 1995), the author states that the features which decide on the attractiveness of a manager are the following:

- high level of education,

- experience both in generating profits and losses,

- continuous progress in promotion including the period of work as a worker - performer,

- specific experience in the area of foreign trade,

- perfect communication skills,

- ability to acquire others' support for the manager's vision,

- self-confidence,

- ability to take risk without excessive stress,

- great honesty.

\section{Experimental}

The title of this subsection is a phrase taken from the publication (WeLCH J., WeLCH S. 2005) from the chapter: Employment. The winners are made from the same mould. The winners are people hired to the positions of: supervisors, managers, leaders by way of the recruitment process. In the BOST study (BORKOWSKI S. 2009), the applied criteria were called the rules $4 \mathrm{E}+1 \mathrm{P}$. Their characteristics are as follows:

$1 \mathrm{E}$ - is full of enthusiasm the whole day,

$2 \mathrm{E}$ - has the ability to stimulate others' actions,

$3 \mathrm{E}-$ takes quick decisions,

$4 \mathrm{E}$ - knows how to implement decisions and strive for realization of goals,

$1 \mathrm{P}$ - cares for their co-workers to be successful.

Based on the rules $4 \mathrm{E}+1 \mathrm{P}$, the supervisors in various companies were assessed. The assessment was made by their subordinates who answered YES or NO to the following characteristics. The results achieved are as follows:

- the level [\%] of YES and NO questions was compared,

- YES/NO quotient was calculated,

- the difference YES - NO was represented graphically,
- the results were presented graphically with the level of YES answers (axis X) and NO answers (axis Y),

- the impact of the personal features (gender, education, age, work experience, mobility, employment type) on the assessment of a supervisor was determined.

\section{Results and discussion}

The results were presented based on the survey conducted amongst the employees of a company producing plastic packaging (RS98). The survey was meant to address the issues mentioned earlier - YES or NO. The recipients number was 55 people, which constitute $85 \%$ of personnel. The Table 1 depicts the structure of answers YES and NO to the following rules $4 \mathrm{E}+1 \mathrm{P}$.

Table 1. Rating structure [\%]. Rules $4 E+1 P$. Refer to RS98

\begin{tabular}{|c|c|c|c|c|c|}
\hline \multirow{2}{*}{ Result } & \multicolumn{5}{|c|}{ Mark of the rule } \\
\cline { 2 - 6 } & 1E & 2E & 3E & 4E & 1P \\
\hline YES & 58.2 & 61.8 & 54.5 & 70.9 & 58.2 \\
\hline NO & 41.8 & 38.2 & 45.5 & 29.1 & 41.8 \\
\hline
\end{tabular}

Source: own study

Table 2. Quotient YES/NO. Rules 4E+1P. Refer to RS98

\begin{tabular}{|c|c|c|c|c|c|}
\hline \multirow{2}{*}{ Result } & \multicolumn{5}{|c|}{ Mark of the rule } \\
\cline { 2 - 6 } & 1E & 2E & 3E & 4E & 1P \\
\hline YES/NO & 1.39 & 1.62 & 1.20 & 2.44 & 1.39 \\
\hline
\end{tabular}

Source: own study

Table 3. Difference YES-NO. The rules $4 E+1 P$. Refer to RS98

\begin{tabular}{|c|c|c|c|c|c|}
\hline \multirow{2}{*}{ Result } & \multicolumn{5}{|c|}{ Mark of the rule } \\
\cline { 2 - 6 } & 1E & 2E & 3E & 4E & 1P \\
\hline YES-NO & 16.4 & 23.6 & 9.0 & 41.8 & 16.4 \\
\hline
\end{tabular}

Source: own study

As the results from Table 1 show, the employees saw in their supervisor an important feature of a leader: he/she knows how to implement decisions and strive for achieving the assigned goals (4E). That regularity has been noticed by $70,9 \%$ of respondents. As it results from the Table 2, the rule of quick decision-making (3E) is characterized by a low value of quotient YES/NO, which means close level of acceptance and negotiations of this leadership value. The observation on the closeness of answer level YES 
and NO, is confirmed in the data of the Table 3. The difference YES NO $<20 \%$ for three rules, means that the supervisor acts differently in specific situations, presumably depending on the guidelines of the owners. It was difficult for the employees to specify, whether their supervisor is enthusiastic all day long (1E), sometimes makes decisions slowly, another day quickly (3E), sometimes he is concerned about his employees' successes, the another day he is not interested in it (1P). The data show that 31\% (17 people) noticed only two rules in their supervisor, whereas 27\% (15 people) considers their supervisor as a leader. The Fig. 1 and 2 present the results of leadership features of a supervisor depending on the personal data of employees.

The Fig. 1presents data referring to the features resulting from the rule $4 \mathrm{E}$. It appears that the major group observing that feature were women (36\% - 20 people) - Fig. 1e. The employees of 31 - 40 years old (marking 2 in the Fig. 1b) were convinced about the leadership features of their supervisor - $42 \%$ voted YES (23 people). $40 \%$ of the people of secondary education (mark 3 in the Fig. 1c) claimed that their supervisor is a leader. $44 \%$ of employees with short work experience of up to 10 years concluded that their supervisor meets the requirements specified in the rule 4E (Fig. 1d). 45\% (25 people) of people hired in the so-called regular mode, i.e. based on the submitted application for work (mark 1 in the Fig. 1e) claim that their supervisor knows how to pursue a defined goal. 31\% (17 people) of employees for whom the current employer is the second one (Fig. 1f) stated that their supervisor meets the rule $4 \mathrm{E}$ in their actions and behavior.

The data in Fig. 2 needs to be interpreted in a similar way,
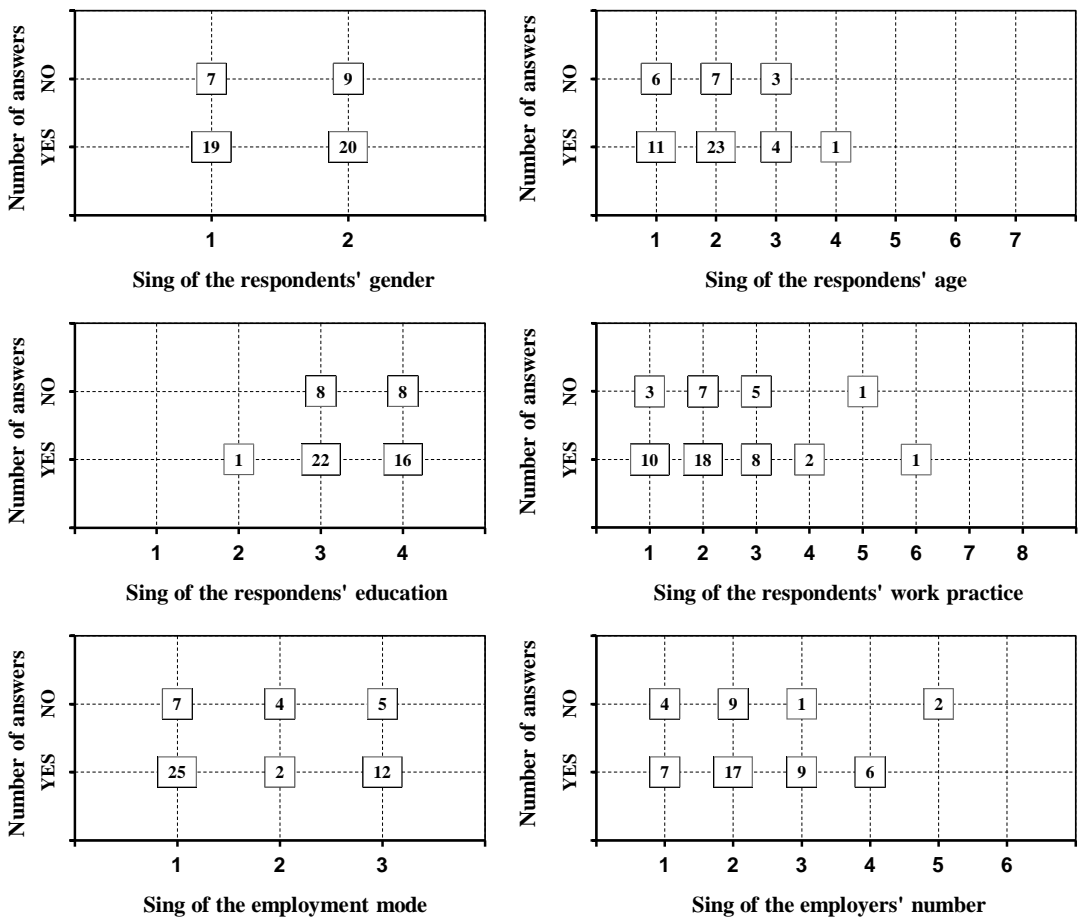

Fig. 1. Frequency of the answers in system YES - NO. Principles $4 E+1 P$. It concerns: a) gender, b) age, c) education , d) work practice, e) mobility, f) mode employments respondents'. Referring to $4 E$ RS98.

Source: own study
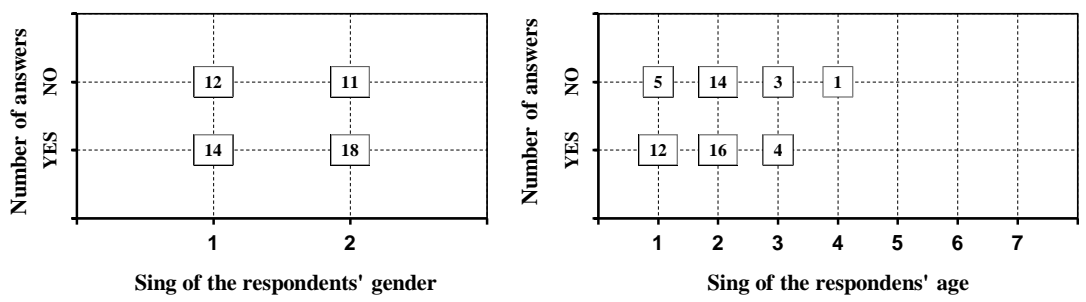

Sing of the respondents' gender

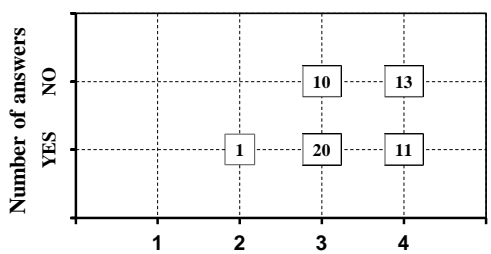

Sing of the respondens' edukation
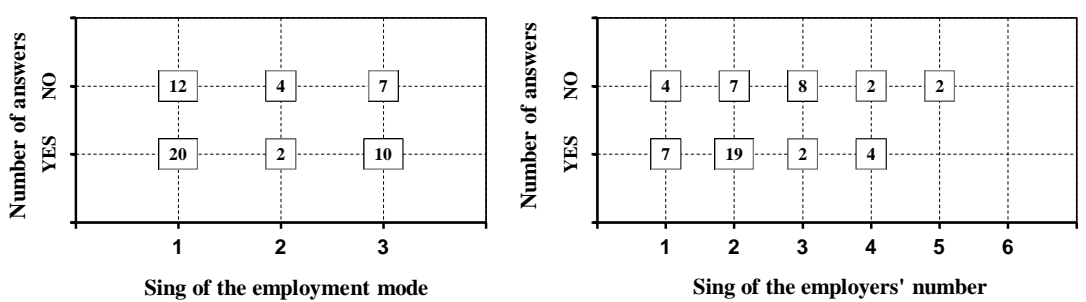

Fig. 2. Frequency of the answers in system YES - NO. Principles $4 E+1 P$. It concerns: a) gender, b) age, c) education, d) work practice, e), mode employments respondents', f) mobility. Referring to 1E RS98.

Source: own study 
however, in reference to the features of a supervisor, as specified in the rule - full of enthusiasm all day long (1E).

\section{Summary}

Based on the analysis of the scientific information included in numerous publications, and based on the preliminary research, it can be observed that:

- in Poland, there is a leading group of scientists in supervision, management and leadership, whose professionalism equals, and sometimes even exceeds, world experts in that area,

- there is a significant diversification of the definitions of the following notions: supervisor, leader, manager and their features,

- leadership, according to Armstrong M., constitutes an acquired skill to a large extent,

- a leader should have many characteristics (HOLLY R. 1980), in particular: intelligence, good results in education, readiness to hold responsibility, activeness, social participation, economic and social status, socialization, initiative, perseverance, knowledge, self-confidence, intuition, full view of a situation, co-operativeness, popularity, ability to adapt to various conditions, eloquence, physical fitness,

- there is a low positive correlation between leadership and age, height, weight, body built, energy, physical appearance, domination and mood control (WAJDA A. 2004),

- the managing personnel (supervisors, directors, leaders, managers) are appointed, evaluated, remunerated, and dismissed by their principals, who at the same time specify the criteria and conditions which need to be met in order to fulfill the assigned role (KoźMINSKI A.K., JEMIELNIK D. 2008),

- while taking decisions, management orders the chaos, which is a synonym of insecurity (KUC B.R. 2004),

- leadership is a sum of predispositions and skills, which should be the characteristics of not only the modern manager but also everyone searching for possibilities to develop in all the spheres of professional and social activities (WAJDA A. 2004),

- „The ugly faces of leadership” endanger its essence, that is effective motivation. Therefore there are discussions held on "the crisis of leadership” (KOŹMIŃSKI A.K. 2008),

- in the process of management, apart from function, the rules, tasks and tools of effective supervision also need to be used (MALIK F. 2007),

- the leadership features of leaders are revealed depending on the conditions of the surrounding environment (internal and external), and situations in which they act,

- the results of preliminary research show that the employees (subordinates) accurately define the leadership features of their supervisors (managers) based on the rules $4 \mathrm{E}+1 \mathrm{P}$.

\section{Literature}

1. KoŹMIŃSKI K.A., JEMIELNIAK D. 2008. Zarzadzanie od podstaw. Wydawnictwo Akademickie i Profesjonalne. Warszawa.

2. NiCKels W. G. 1995. Zrozumieć biznes. Wyd. Bellona. Warszawa.

3. MALIK F. 2006. Kierować-osiagać-żyć. Skuteczne zarzadzanie na nowe czasy. Wydawnictwo MT Biznes. Warszawa.

4. FOŁTYN H. 2009. Praca wspótczesnych menedżerów. Wydawnictwo Naukowe Wydziału Zarządzania Uniwersytetu Warszawskiego. Warszawa.

5. PoCZTOWSKI A. 1998. Zarządzanie zasobami ludzkimi. Zarys problematyki i metod. Wyd.Antykwa. Kraków.

6. KuC B. R. 2004. Od zarządzania do przywództwa. Wydawnictwo Menedżerskie PTM. Warszawa.

7. WeLCH J. WeLCH S. 2005. Winning znaczy zwycięzać. Wyd. Studio EMKA. Warszawa.

8. BORKOWSKI S. 2009. Zasady zarzadzania TOYOTY w pytaniach. Wyniki badań BOST. Wydawnictwo Menedżerskie PTM. Warszawa.

9. Holly R. 1980. Koncepcja przywództwa nieformalnego w małych grupach społecznych. Studia socjologiczne 2.

10. WAJDA A. 2004. Organizacja $i$ zarzadzanie. Wydawnictwo PWE. Warszawa. 